\title{
The Right to Nationality and the Reduction of Statelessness - The Responses of the International Migration Law Framework
}

Nafees Ahmad*

DOI: $10.21827 / 59 \mathrm{db} 69 \mathrm{~b} 590 \mathrm{f} 71$

\begin{abstract}
Statelessness is the absence of the right to have a legal connection between nationality and state. The state of nationality is an identity to enjoy a 'right to have rights'. Statelessness disrupts the enjoyment of all the rights which are generally perceived or purported to have been granted for all including inter alia the right to work, the right to vote, the right to health, the right to welfare benefits or welfare and a child's right to education. Statelessness precludes people from relocating and proliferates their chances of arbitrary arrest, confinement or detention with no adequate answers. Succinctly averring, statelessness demotes and generates a state of irrelevance among the people with no hope of their condition ever improving, no possibility for a better future for themselves or their posterity. The state of statelessness dismantles the idea of cohesive human existence in a civilized world. Therefore, statelessness is a deprivation of a range of rights and benefits that bestow upon individuals constitutional identity, national security and state protection popularly known as nationality or citizenship. Statelessness may be imputed to a catena of causes inter-alia administrative practices, conflict of laws, discrimination, denationalization, matrimonial litigation, non-registration of births, persecution, renunciation, transfer of territories, re-demarcation of new boundaries, state succession, terrorism, climate change and forced displacement and migration. But its magnitude and scale still remains to be mapped because the problem of statelessness is a new predicament for international law and its offshoots. It has emerged as an ordeal for the international community that has to attend to the plight of 10 million stateless persons worldwide. Thus, it is abundantly clear that the United Nations High Commissioner for Refugees' (UNHCR) mandate is well founded in light of the sheer amount of stateless persons. Furthermore, there are also at least 1.5 million stateless refugees and around 3.5 million stateless refugees from Palestinian origin whose problems have posed challenges to the international law framework. In this paper, an attempt has been made to decipher the miasma of statelessness while locating the right to nationality of stateless persons. Suggestions are made with respect to how to end and ensure the reduction of statelessness under the architecture of international law within
\end{abstract}

$\mathrm{PhD}$, LLM, Author teaches at the Faculty of Legal Studies, South Asian University (An International University Established by the Eights SAARC Nations)-New Delhi, author is an Indian national who holds a Doctorate (Ph.D.) in International Refugee Law and Human Rights. Author writes on International Forced \& Irregular Migrations, Human Displacement, Climate-Change Refugees, Refugee Studies, Asylum Policies, Human Trafficking in Refugees and Migrants, Durable Solutions, Diplomacy, International Relations, Extradition and SAARC Issues. Author has conducted research on Internally Displaced Persons (IDPs) from Jammu \& Kashmir and North-East Region in India and has worked with several research scholars from US, UK and India and consulted with several research institutions and NGO's in the area of human displacement and forced migration. Dr. Ahmad has introduced a new Program called Comparative Constitutional Law of SAARC Nations for LLM along with International Human Rights, International Humanitarian Law and International Refugee Law. nafeestarana@gmail.com,drnafeesahmad@sau.ac.in 
and beyond the pragmatism of international relations, diplomatic narratives and orientations engrossed in Occidentalism and orientalism.

\section{Introduction}

While statelessness has long been recognised as an important problem in international law, the desire of states to exercise control over stateless persons in their jurisdictions has prevented effective action. The 1954 Convention Relating to the Status of Stateless Persons has attracted only 86 signatories, and a mere 61 states have ratified the United Nations Convention on the Reduction of Statelessness of 1961. The indifference of national governments and the inaction of the international community have affected a large number of persons who are particularly vulnerable to oppression because they lack the protection afforded by rights of citizenship. The stateless are 'denied the vehicle for access to fundamental rights, access to protection and access to expression as person(s) under the law. ${ }^{1}$ However, the entire gamut of statelessness has to be addressed within the framework of International Law. The problem of statelessness has posed new challenges to the international community that is mired in a responsibility shifting game. Presently, there are 10 million stateless persons worldwide who are under the UNHCR's protection mandate. In addition, there are also around 3.5 million Palestinian stateless persons in need of international protection. ${ }^{2}$ The real number of stateless persons, however, is probably drastically greater due to data gaps. Therefore, the collection of proper data on statelessness would definitely pave the way to pro-actively bring the problem to its logical conclusion.

Nowhere is the problem of statelessness more acute than in South and South East Asia. Sri Lankan repatriates in India, Burmese refugees in Cambodia, and many ethnic Chinese in all parts of South East Asia are currently stateless and, thus, especially vulnerable to the same types of human rights abuses as those suffered by Chakmas and Hajongs of Arunachal Pradesh. ${ }^{3}$ The United Nations High Commission for Refugees has been actively involved since 1991 in addressing refugee-related problems in the states of the former Soviet Union. Already, the scores of people are on the move, ${ }^{4}$ either displaced by conflicts or returning to their places of origin. The new states lack the resources and the institutional capacity both to absorb flows of peoples and to deal effectively with the problems associated with population movements.

Over 200 different ethnic groups lived for centuries within the cultural mosaic of the Russian Empire. The Social Federal system that emerged from the Bolshevik ${ }^{5}$ revolution was based on a hierarchy of different ethnic groups. Artificial borders were drawn to divide national groups ${ }^{6}{ }^{6}$ decreasing the likelihood of threats to the central government in Moscow. Stalin's policies of relocation and colonization still have

1 As of 1 September 2016, 89 States were party to the 1954 Convention on Statelessness and as of May 2016, 69 States have become the parties to 1961 UN Convention on Reduction of Statelessness, See; Batchelor, CA, "Stateless Persons: Some Gaps in International Protection" 7(2) International Journal of Refugee Law (1995) 232, 235.

2 Van Waas, L, De Chickera, A and Albarazi, Z, The World's Stateless: A New Report on Why Size does and doesn't Matter (Institute of Statelessness and Inclusion 2014).

3 Limpert, NA, "People Without a Country" Seminar 463, March 1998, (Yale University, New Haven, USA).

4 Ibid.

5 The October Revolution of 1917 that established the ideology of Marxism in Russia and new government decreed the abolition of private land ownership and set up a dictatorship of the Proletariat. In 1923, the Union of Soviet Socialist Republics came into being.

6 Qualls, KD, "The Russian Revolutions: The Impact and Limitations of Western Influence" Dickinson College Faculty Publications Paper 8 (2003). 
repercussions today. Balts, Poles, Chechens, Germans, Kalmyles and the Crimean Tatars, ${ }^{7}$ to name a few, were among those forcibly relocated in Central Asia and Siberia. At the same time, Stalin and subsequent Soviet leaders encouraged large numbers of Russians to settle in non-Russian republics of the former USSR. ${ }^{8}$ These population movements had the effect of diluting the ethnic homogeneity ${ }^{9}$ of each republic and reducing the titular nationality and other non-Russian minorities to lesser status.

\section{International Law on Statelessness: Historical Development}

The state is not a private club, which can induct or expel members arbitrarily. Rather, the development of customary international law has placed certain limitations upon states as regards the conferment of citizenship. The 1930 Hague Convention was one of the first documents to recognise those limitations. Article I of the Convention states:

It is for each state to determine under its own law who are its nationals. This law shall be recognised by other states in so far as it is consistent with international conventions, international custom, and the principles of law generally recognised with regard to nationality. ${ }^{10}$

Therefore, decisions regarding the acquisition or loss of nationality will be recognised only insofar as they are consistent with contemporary legal norms. Currently, these norms are expressed in the 1954 U.N. Convention Relating to the Status of Stateless Persons (entered into force 1960) and the 1961 U.N. Convention on the Reduction of Statelessness (entered into force 1975). Prior to the 1954 Convention statelessness was viewed merely as an indication of one's status as a refugee. The mandate of the 1946 Intergovernmental Committee on Refugees did not mention statelessness at all and, thus, the committee regarded de jure and de facto stateless merely as one of the criteria of eligibility to determine the refugee status in conjunction with others, ${ }^{11}$ e.g. flight into one's home state as a result of racial, political or religious persecution.

As the definition of refugee status was being continually narrowed during the 1940s, many stateless persons could no longer receive the protection afforded by the League of Nations High Commission for Refugees, (LNHCR), the Inter-governmental Commission for Refugees, or the International Refugee Organisation.12 This led the Commission on Human Rights to request that 'early consideration be given by the United Nations to the legal status of persons who do not enjoy the protection of any government, in particular pending the acquisition of nationality', ${ }^{13}$ as regards their legal and social protection and their documentation in the countries of reception.

7 Kotkin, S, "1991 and the Russian Revolution: Sources, Conceptual Categories, Analytical Frameworks" 70(2) The Journal of Modern History (1998) 384.

8 Georgy Malenkov, Nikita Khrushchev, Leonid Brezhnev, Yuri Andropov, and Konstantin Chernenko encouraged the mainland Russians to move and settle in non-Russian settlements in the USSR.

9 Iogna-Prat, M, "Nationality \& Statelessness Issues in the Newly Independent States" in GowllandDebbas, V, ed, The Problem of Refugees in the Light of Contemporary International Law Issues (Martinus Nijhoff, The Hague, 1996), 25-31.

10 League of Nations, Convention on Certain Questions Relating to the Conflict of Nationality Law, 1930, 179 TS 89.

11 Intergovernmental Committee on Refugees, Statelessness and Some of its Causes: An Outline, (Intergovernmental Committee on Refugees, London, 1946), 2.

12 Batchelor, supra nt 1, 240.

13 UN Economic and Social Council, Report of the Commission on Human Rights, 17 December 1947 (2nd Session) E/600. 
Seven years were to pass, however, before the U.N. was to take action upon this recommendation. During the consideration of the 1951 Convention Relating to the Status of Refugees, the problem of statelessness was put aside for lack of time. ${ }^{14}$ In view of the urgency of the refugee problem and the responsibility of the United Nations in this field, the Committee decided to first address the problem of refugees, whether stateless or not, and to leave to later stages of its deliberations the problems of stateless persons who are not refugees. ${ }^{15}$

This is a recurring theme central to the development of statelessness rights in international law. Moreover, the stateless persons have been neglected because their grievances, anxieties and concerns have been viewed as sequel to greater problems. These issues require a diversified mechanism of investigation and redress based on pragmatism.

The 1954 Convention Relating to the Status of Stateless Persons was an early attempt to deal with the problem of statelessness in its own right. The Convention requires states to grant stateless persons many of the same rights accorded to citizens under national law. It also protects stateless persons from expulsions in all but exceptional circumstances. However, through an apparent oversight, ${ }^{16}$ no provision was made for a supervisory body similar to the U.N. High Commission for Refugees. Additionally, the definition of a stateless person is provided under 1954 convention as '[a] person who is not considered as a national by any state under the operation of its law. ${ }^{17}$ The aforesaid definition is couched in general terms and excludes large numbers of persons who have no effective nationality. For example, among the massive numbers of boat people ${ }^{18}$ from Vietnam were ethnic Chinese who had never set foot in either Mainland China (PRC) or Taiwan (ROC). The People's Republic does not recognize them at all, and the ROC grants them merely 'over-seas nationality.' Those granted overseas nationality have no necessary right of entry or residence in Taiwan. Thus, while these ethnic Chinese are technically considered nationals under Taiwanese law, they receive none of the benefits of citizenship and are effectively stateless. Nonetheless, they are not considered stateless persons under the 1954 Convention. ${ }^{19}$

The 1961 Convention on the Reduction of Statelessness defines stateless persons in the same manner as the 1954 Convention. Additionally, unlike the 1951 Convention relating to the Status of Refugees, this convention was not promulgated for the purpose of providing assistance to a specific group of people. The authors of the Convention tended to view their work as little more than codifying existing practice regarding the recognition of nationality judgements. Further, a proposal to create an independent tribunal for stateless persons to press nationality claims was quickly squashed. ${ }^{20}$

A document drafted under such conditions was not likely to greatly improve the condition of stateless persons, nor has it. However, Article 11 of the convention did provide for a relief agency to deal with the problems of the stateless. The UNHCR was charged with the responsibilities of Article 11 and, thus, the problem of statelessness was again connected to, and to some degree overshadowed by, the concerns of refugees. For

\footnotetext{
14 Limpert, supra nt 3.

15 UN Economic and Social Council, Report of the Ad hoc Committee on Statelessness and Related Problems, 26 January 1950, (1st Session) E/AC.32/SR.3.

16 Batchelor, supra nt 1, 246.

17 Article 1, UN Convention Relating to the Status of Stateless Persons (1954) 360 UNTS 117.

18 Pugh, M, "Drowning not Waving: Boat People and Humanitarianism at Sea" 17(1) Journal of Refugee Studies (2004) 50.

19 Batchelor, supra nt 1, 233.

20 Batchelor, supra nt 1, 252.
} 
nearly 30 years following the 1961 convention, the problem of statelessness was given little attention by the international community.

The right of all persons to a nationality ${ }^{21}$ was reiterated in the International Convention on Civil and Political Rights ${ }^{22}$ and the Convention on the Rights of the Child $^{23}$ but again, no specific ${ }^{24}$ measures or procedures were mandated. Although the provisions of the 1985 Declaration on the Human Rights of Individuals who are not nationals of the country in which they live applied to stateless persons and established the fundamental rights of aliens, the declaration was addressed to aliens more generally (especially guest workers) and does not elaborate upon or even mention the fundamental right to a nationality established by Article 15 of the Universal Declaration of Human Rights. ${ }^{25}$ Thus, the right to have a nationality was created and designed basically to eliminate the menace of statelessness.

The issue of citizenship has received greater attention recently in response to the nationality legislation of the newly created states of Central Asia and the former Yugoslavia. In response to the growing numbers of stateless persons, the Executive Committee of the High Commissioner's programme has recommended that UNHCR strengthen its efforts in this domain. Efforts include promoting accession to the Convention on the Reduction of Statelessness and the Convention relating to the Status of Stateless Persons, training for UNHCR staff and government officials, and a systematic gathering of information on the dimension of the problem and to keep the Executive Committee informed of these activities. ${ }^{26}$ Further, the Executive Committee has adopted the Conclusion on the Prevention of and Reduction of Statelessness and the Protection of Stateless Persons, which reiterate the need for the UNHCR to more actively promote the welfare of stateless persons. ${ }^{27}$

The United Nations former High Commissioner for Refugees has also noted that the UNHCR has a 'special responsibility' for stateless persons and that her office has been designed as an intermediary between states and stateless persons under the 1961 convention. Most recently, UNHCR has been requested by its executive committee to place the matter of stateless on its agenda. We will explore promotional and preventive activities to which UNHCR can contribute in collaboration with concerned states. There is an obvious link between the loss or denial of national protection and the loss or denial of nationality. On the plane of rights, the prevention and reduction of statelessness is an important aspect of securing minority rights. ${ }^{28}$

21 Article 15, Universal Declaration of Human Rights, December 10, 1948, See also, Griffin, WL, "The Right to a Single Nationality" 40 Temple Law Quarterly (1966) 58.

22 Article 24, International Covenant on Civil and Political Rights (ICCPR), 1966, 999 UNTS 171.

23 Van Bueren, G, The International Law on the Rights of the Child (Kluwer Law International 1998), 366; See Veerman, PE, The Rights of the Child and the Changing Image of Childhood (Martinus Nijhoff Publishers 1992), 171.

24 Ibid.

25 Limpert, supra note $3,42-43$.

26 UNHCR, Report of the 45th Session of the Executive Committee of the High Commissioner's Programme, 7 October 1994, A/AC. 96/839, para 19.

27 UNHCR, Conclusion on the Prevention and Reduction of Statelessness and the Protection of Stateless Persons, 6 October 2006, (56th Session) 106 (LVII).

28 Ogata, S, UNHCR, Statement to the 51st Session of Commission for Human Rights, 1995. 


\section{Nationality and Statelessness: Problems and Prospects}

The classical view is that, in principle, questions of nationality fall within the domestic jurisdiction of each state. According to Brownlie, ${ }^{29}$ the evidence is overwhelmingly in support of the view that the population follows the change of sovereignty. According to State practice analysed by Brownlie, there is a general presumption that persons attached to a territory will ipso facto lose their former nationality and acquire the nationality of the new State. Nationality would change when sovereignty changed hands. Attachment generally means substantial connection with the territory concerned by citizenship, residence or family relations to a qualified person. The link of the people with the territory is said to be in accord with human and political reality. ${ }^{30}$

Other scholars do not share this view. O'Connel ${ }^{31}$ argues that, undesirable as it may be for any person to become stateless as a result of a change of sovereignty, it cannot be asserted with any measure of confidence that international law, at least in its present stage of development, imposes any duty on the successor State to grant its nationality. Weis ${ }^{32}$ holds the view that there is no rule of international law under which the nationals of the predecessor State shall acquire the nationality of the successor State. There is only a presumption in international law that the acquiring State would, through municipal law, confer its nationality on the former nationals of the predecessor state.

Looking from a different angle, $\mathrm{Chan}^{33}$ considers that, upon a change of sovereignty, all persons who have a genuine and effective link with the new State will automatically acquire the nationality of the new State. It is within the competence of each State to determine what constitutes a genuine and effective link in the granting of its nationality, subject to the presumption of avoidance of statelessness and the duty not to apply any law on a discriminatory basis, which would be in contradiction with Article 15(2) of the Universal Declaration of Human Rights. It is also a settled rule of customary international law that residents of the transferred territory who have a nationality other than that of the predecessor State are not affected by the change of sovereignty.

Municipal law determines the rules of nationality. However, due to the absence of uniformity and coherence in State laws pertaining to the institution of nationality various inconsistencies and difficulties arise. This has resulted in considerable problems and issues of statelessness, double nationality and conflicting citizenship laws. In recent years a new trend can be observed with respect to migration. At the end of the twentieth century individuals are now regarded as subjects of international law. Consequently, national boundaries are losing their meaning and human mobility is being propelled by a human rights agenda. The root of the refugee problem for one can be linked to various human rights issues. However, the majesty and supremacy of democratic and republican vision, values, and principles such as the rule of law, equality, liberty, free speech, universal fraternity, gender justice, peace and harmony must be upheld as the benchmarks ${ }^{34}$ of human civility beyond the rubrics of power politics. Therefore, any circumvention and transgression of these core values by the governmental instrumentalities and state machinery is tantamount to creating human rights problems and statelessness challenges.

29 Brownlie, I, Principles of Public International Law (4th ed, Oxford University Press, 1990).

30 Iogna-Prat, supra nt 9, 28.

31 O'Connell, DP, State Succession in Municipal and International Law (2nd ed, Cambridge University Press, 1967).

32 Weis, P, Nationality and Statelessness in International Law (2nd rev ed, Sijthoff and Noordhoff, 1979).

33 Chan, JM, "The Right to a Nationality as a Human Right" 12 (1) Human Rights Law Journal (HRLJ) (1991) 3.

34 Achiron, M, Nationality and Statelessness: A Handbook for Parliamentarians (UNHCR Press 2005). 
At the Hague Conference of 1930 an endeavour was made to end the conflicts arriving out of divergent State laws in respect of nationality. This resulted in the Convention on Certain Questions Relating to the Conflict of Nationality Laws being adopted. In the Convention an attempt was made to resolve the problems relating to nationality and statelessness. A subsequent agreement addressing these issues has been the Convention of the Nationality of Married Women, which was adopted in $1957 .{ }^{35}$

It is now axiomatic that State laws mostly determine nationality. Nationality is the principle link between an individual and International law. ${ }^{36}$ Therefore, it shows the importance of nationality at the pedestal of international law. Under international law, nationality has often been used as a justification for the intervention of a government to protect another State. ${ }^{37}$ It may, however, be noted that international law does not create a correlative right in favour of the individuals. It creates rights only in favour of the states whose nationals they are. ${ }^{38}$

In the Paneyezys Saldutiskis case the Permanent Count of International Justice held

in taking up the case of one of its nationals, by restoring to diplomatic action or international judicial proceedings on his behalf, a State is in reality asserting its own right, the right to ensure in the persons of its nationals, respect for the rules of international law: The right is necessarily limited to intervention on behalf of its own nationals because, in the absence of special agreement, it is the bond of nationality between the state and individual which alone confers upon the state the right of diplomatic protection, and it is a part of the function of diplomatic protection that the right to take up a claim and ensures respect for the rules of International law must be envisaged. ${ }^{39}$

The great jurist of international stature J.G. Starke also underlined the international importance of nationality in the following observations: ${ }^{40}$

(I) The protection of rights of diplomatic agents is the consequence of nationality.

(II) If a State does not prevent offences of its nationals or allows them to commit such harmful acts as might affect other states, then that state shall be responsible for the acts committed by such a person.

(III) Ordinarily, states do not refuse to take the persons of their nationality. By nationality we mean loyalty towards particular state.

(IV) Nationality may also mean that the national of a State may be compelled to do military service for the state.

(V) Yet another effect of nationality is that the state can refuse to extracts its own nationals.

(VI) According to the practice of a large number of states during war, enemy character is determined on the basis of nationality.

35 Kapoor, SK, International Law, (11th ed, Central Law Agency, 1996), 290-291.

36 Jennings, R and Watts, A, Oppenheim's International Law, (9th ed. Vol. I, Oxford University Press, 1992) 857.

37 Ralston, J and Permanent Court of International Justice, The Law and Procedure of International Tribunals: Being a Résumé of the Views of Arbitrators upon Questions Arising Under the Law of Nations and of the Procedure and Practice of International Courts, (Stanford University Press, 1926), 137-160.

38 Kapoor, supra nt 35.

39 PCIJ, Panevezys-Saldutiskis Railway (Preliminary objections), PCIJ Series E, No. 15. 91-97.

40 Starke, JG, Introduction to International Law, (10th ed. Butterworths, Singapore, 1989), 342-343. 
(VII) States frequently exercise jurisdiction over criminal and other matters over the persons of their nationality.

In a catena of cases it has been found by the PCIJ that States may take out of national jurisdiction to international jurisdiction for rapid and pragmatic resolution. ${ }^{41}$

\section{A. Open Questions in the Context of International Law}

There are various questions agitating the minds of the community of States requiring reflection and contemplation. These questions have been identified and put into two questions in the context of public international law in the following words:

The first area of issues centres on international law aspects of matters of nationality. ${ }^{42}$ In international law, is there a recognised right to a nationality? If the answer is positive, which state has an obligation to grant nationality? How is the genuine $\operatorname{link}^{43}$ between the state and the individual established by the nationality laws? What are the contemporary functions ${ }^{44}$ of the law of nationality? What is the content of the right to nationality as a human right? Are there common international standards ${ }^{45}$ in regard to the elimination/reduction/prevention ${ }^{46}$ of the statelessness? How are such efforts to eliminate/reduce/prevent statelessness compatible with the concept of national sovereignty?

The second area of issues is related to the nationality qualification ${ }^{47}$ under public international law in the wake of disintegration ${ }^{48}$ of the various nations - states that create the adverse consequences ${ }^{49}$ for the smooth resolution of nationality matters. The disintegration of various nations and States raise some questions concerning its qualification under public international law. These questions have been raised by the disintegration of countries such as the Soviet Union, Yugoslavia, and Czechoslovakia. Apart from statelessness by disintegration, statelessness is also caused by internal civil strife, insurgency within the country, and armed conflict and rebellion. This is also known as internal displacement.

In recent years a new class of people is emerging and attracting the attention of the refugee workers. These people are also known as internally displaced persons (IDPs). Their displacements are being caused by the environmental imbalances due to rapid and

41 PCIJ, Tunis Morocco Nationality Decrees (Advisory Opinion), PCIJ Series B No. 4; PCIJ, German Settlers in Poland (Germany v Poland), PCIJ Series A No.7, 16; PCIJ, German Interests in Upper Silesia (Germany v Poland), PCIJ Series A No.6, 14, para 16 and PCIJ, Treatment of Polish Nationals in Danzig Territory (Advisory Opinion), PCIJ Series A/B 44, para 121.

42 Hailbronner, K, Nationality in Public International Law and European Law, at <http://eudocitizenship.eu/docs/chapter1_Hailbronner.pdf> accessed on 29 August 2017.

43 Jennings, R and Watts, A, supra nt 36.

44 Sloane, RD, "Breaking the Genuine Link: The Contemporary International Legal Regulation of Nationality” 50(1) Harvard International Law Journal (2009) 1.

45 Ibid.

46 Howard, MM, "Variation in Dual Citizenship Policies in the Countries of the EU" 39(3) International Migration Review (2005) 697.

47 Bauböck, R, et al (eds.), EU Project: The Acquisition of Nationality in EU Member States: Rules, Practices and Quantitative Developments (NATAC), (Institute for European Integration Research Austrian Academy of Sciences 2006).

48 Rotberg, RI (ed.), State Failure and State Weakness in a Time of Terror (World Peace Foundation 2003), See also Rotberg, RI, "The New Nature of Nation-State Failure" 25 Washington Quarterly (2002), 85-96; Rotberg, RI, "Failed States in a World of Terror" 81 Foreign Affairs (2002) 127.

49 Handelman, D, "Contradictions between Citizenship and Nationality: Their Consequences for Ethnicity and Inequality in Israel" 7(3) International Journal of Politics, Culture and Society (1994) 441. 
reckless industrialisation, disregard of eco-systems, depletion of the ozone layer, greenhouses effects, gaseous emissions, construction of gigantic thermal power projects, sporadic conflagration in the jungles of southeast Asian nations including recent fire in the Canadian jungles, and building of big dams. These actions of humanity initiated in the name of development have resulted in the creation of a new class of people known as 'environmental refugees'. This type of refugee does not find any protection whatsoever in the existing definition of the word refugee as enshrined in Article 1 of the 1951 Convention Relating to the Status of Refugees.

The exclusion of a growing type of refugee is highly problematic and requires that the definition of a refugee be re-visited in light of these developments. Moreover, this situation requires humanitarian solutions in consonance with the parameters set by the umbrella of human rights norms and standards. It is, thus, essential that the definition of refugee be reformulated and re-defined accordingly.

\section{B. Nationality and Statelessness: Definition and Meaning}

An individual's nationality forms a continuing status and not a physical fact, which occurs at a particular moment. Nationality is a continuing legal relationship between the sovereign State on the one hand and the citizen on the other. The fundamental basis of an individual's nationality is membership in an independent political community. This legal relationship involves rights and corresponding duties upon both, the citizens and the State. ${ }^{50}$ Nationality may be defined as the bond, which unites a person with a given State. This constitutes his membership in the particular State, which gives him a claim to the protection of that State and which subjects him to the obligations created by the laws of that State. ${ }^{51}$ Nationality is a legal bond having as its basis a social fact of attachment, a psychological and sentimental connection to one's homeland together with the existence of reciprocal rights and duties. It may be said to constitute a juridical expression of the fact that the individual upon whom citizenship is conferred either directly by the law or as a result of an act of the authorities is in fact more closely connected with the population of the State conferring nationality than with that of any other State. ${ }^{52} \mathrm{In}$ United States of American V. Wong Kum Ark ${ }^{53}$ Justice Gray propounded that the State may determine what type or class of people shall be entitled to citizenship. A State cannot claim that the rules relating to the acquisition of nationality that it has laid down are entitled to recognition by another State unless the former has acted in conformity with this general aim of ensuring that the legal bond of nationality in accordance with an individual's genuine connection with the State is established. The State granting nationality, therefore, assumes the obligation to defend its citizens against other States. ${ }^{54}$ Thus, nationality may be defined 'as the legal status of membership of the collectively of individuals whose acts, decisions and policy are vouchsafed through the legal concept of the state representing those individuals. ${ }^{, 55}$

On the other hand, the International Law Commission considered the problem of statelessness in 1954 and the first Convention Relating to the Status of Stateless persons was opened for signature at New York on 28 September in the same year. A stateless person is defined under Article 1 of the aforesaid convention: 'The term 'stateless

50 Iogna-Prat, supra note 9, 27.

51 Lynch, R, "British Mexican claims Commission" Annual Digest of Public International Law cases (19291930) 221-228.

52 Fenwick, CG, International Law, (3rd ed. Century Co., 1971), 301-302.

53 ICJ, Nottebohm Case (Liechtenstein v. Guatemala), ICJ Reports 1955, 6 April 1955.

54 U.S. Supreme Court, United States of America v Wong Kim Ark, 169 U.S. 649 (1898).

55 Fenwick, supra nt 52. 
persons' means a person who is not considered as a national by any state under the operation of its law. ${ }^{56}$

\section{The UN Convention on the Reduction of Statelessness, 1961: Main Provisions and Remedial Steps to be Taken}

Thereafter, the issue of reduction of statelessness was deliberated by the General Assembly and a conference was convened to conclude a Convention on the Reduction of Statelessness in 1961. The Convention was adopted in same year. The main provisions of the Convention ${ }^{57}$ make ample avenues to a state to grant its nationality to a person born in its territory who would otherwise be stateless and such a nationality shall be granted either by birth or by operation of law. ${ }^{58}$ Any foundling found in the territory of a Contracting State shall be considered to have been born within that territory to parents possessing the nationality of that state ${ }^{59}$ unless evidence to the contrary is provided. Birth on a ship or in an aircraft shall be deemed to have taken place in the territory of the state whose flag the ship flies or in the territory of the state in which the aircraft is registered as the case may be. ${ }^{60}$ Further, a Convention party shall also grant its nationality to a person whose parent was at the time of birth the national of that state party subject to certain conditions as per the operation of law. ${ }^{61}$ However, loss of nationality as a result of any change in the personal status of a person such as marriage, termination of marriage, and adoption, shall be conditional upon possession or acquisition of another nationality. ${ }^{62}$ In this context, a person shall not be deprived of his nationality so as to become stateless on the ground of departure, residence abroad or failure to register. ${ }^{63}$ Naturalization abroad or renunciation of citizenship shall not result in loss of nationality unless the person concerned acquires another nationality. ${ }^{64}$ Generally, a person shall not lose the nationality of the state party to the convention if such loss renders him stateless ${ }^{65}$ contrary to the mandate of the Convention.

Therefore, the challenge of reducing statelessness and obliterating the impediments arising therefrom must be addressed with remedial measures. Such measures could be that state parties develop well-considered grounds on which the definite nationality of a person is based. A state may recognise such nationality or choose not do so. Therefore, the Hague Convention and its subsequent improvement in the form of the convention on the Reduction of Statelessness, 1961 must be adhered to by the state parties by way of general incorporation into domestic legislation. Additionally, states must not deprive individuals of their nationality except when there is a sufficient and plausible cause backed by due process and a procedure established by law. Further, the fundamental principles of universal liberty, equality and fraternity must constitute the criterion of granting nationality to the stateless persons, and stateless persons must be bestowed upon some rights through international treaties and instruments while incorporating the same in municipal legal systems at par with nationals of their country of refuge. Thus, the grant of nationality must be liberal and in conformity with the

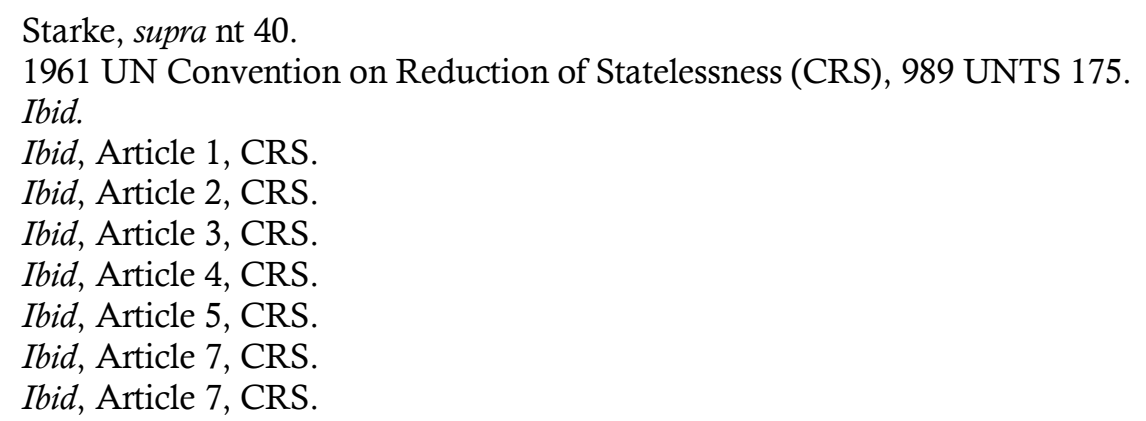


mandate of International Conventions thereon inter-alia basic tenets of Universal Declaration of Human Rights. However, the procedural difficulties and administrative processes must be simplified to be less time consuming at the national and international level. Statelessness issues and their solutions must be dealt with in a sensitive manner and in tune with fundamental paradigms and principles of egalitarian values and human rights norms. State sovereignty and demography must not come in the way of granting nationality to the stateless. Moreover, stateless persons must be encouraged to contribute their professional skills and expertise to the welfare of the receiving state while ensuring the stateless individuals' socio-economic improvement by the state. Moreover, dissemination of information and awareness of their rights must also be pursued.

Thus, it is evident that there are still numerous obstacles and hurdles, which require a positive and pragmatic solution. The aforesaid suggestion must be taken care of and further efforts to mitigate grievances within the legal parameters of a domestic regime need to be undertaken. Much still remains to be done. The deprivations of nationality of Ugandan-Asians and Bihari-Muslims in Bangladesh have, in recent years, attracted the attention of the international community. On this, Justice V.R. Krishna Iyer has deftly remarked:

Statelessness is sought to be minimised and grant of nationality liberalised and obligated. And if nationality is ensured to a person, he acquires political rights, which stand four squares between the offending state and the expelled. The Ugandan Asians, for instance, without complete disregard of the convention of the statelessness cannot be deported. Nor can any particular racial groups be deported on the arbitrary fiat of any rule. ${ }^{66}$

Therefore, statelessness is a situation that snaps the legal connection between state and nationality and leaves a person in limbo. The conferment of nationality bequeaths upon a person an identity to enjoy a range of benefits in the trajectory of 'right to have rights' ${ }^{167}$ that are made available to all human beings who are considered to exist nowhere. The right to have rights has been there even for savages who lived in some kind of a social order ${ }^{68}$ Consequently, rights are even available to those persons who live beyond the pale of any civilization including the Stylites (a Christian ascetic living atop a pillar) of the antiquity. Thus, statelessness spoils the gratification of having all human rights necessary for a civilized human survival. In the modern world, all the human rights as enumerated in the International Bill of Human Rights ${ }^{69}$ inter-alia the right to work, the rights to vote, the right to health, the right to welfare benefits or welfare, a child's right to education and the right to have a nationality are inalienable and indispensible to the core of civilization. However, statelessness creates difficulties for people who want to travel and multiplies the possibilities of their arbitrary arrest or wrongful confinement. In a nutshell, statelessness germinates the seeds of human worthlessness and creates a state of hopelessness among the stateless persons with no change and improvement in their refugee-like situations. Therefore, statelessness deprives people of many legal entitlements in a geo-political entity such as legal personality, human security, and state

${ }^{66}$ Krishna Iyer, VR, "Mass Expulsion as Validation of Human Rights" 13(2) Indian Journal of International Law (1973), 169-171.

67 Arendt, H, The Origins of Totalitarianism (Harcourt Books 1994), 292.

68 Ibid.

69 The International Bill of Human Rights consists of the Universal Declaration of Human Rights of1948, the International Covenant on Economic, Social and Cultural Rights of1966, and the International Covenant on Civil and Political Rights of1966 and its two Optional Protocols. 
protection, which can only be enjoyed if nationality or citizenship is bestowed upon them. Further, there is no single cause of generating statelessness; it is caused by a plethora of circumstances ${ }^{70}$ and circumventions. For example; state practices, conflict of legal jurisdictions, conjugal causes, discriminatory state behaviour, denationalization, non-registration of births, renunciation, state succession, exchange and transfer of territories, re-drawing of new borders, irregular migration, climate change-induced forced displacement, persecution ${ }^{71}$ and terrorism.

\section{The United Nations High Commissioner for Refugees' Involvement in Nationality and Statelessness Matters}

The UNHCR has a worldwide responsibility for solving the refugee problem. But, upon request of the United Nations Secretary General, the UNHCR is more and more taking upon itself the responsibility to care for persons who are displaced either externally or internally i.e. internally displaced persons (IDPs). The UNHCR is presently involved in emergency operations in the former USSR, Yugoslavia and East Pakistan (now Bangladesh) where massive displacements of persons occurred in Georgia, Armenia, Azerbaijan, Tajikistan, Bosnia \& Herzegovina, Croatia, Serbia, Kosovo and Bangladesh. In these regions, the UNHCR has approached persons who are stateless and do not have any sort of national legal protection.

In these countries, the UNHCR is also frequently requested to provide support in building up legal systems aimed at protecting refugees, displaced persons and stateless persons, and has been associated with the drafting process of nationality laws or amendments to the existing nationality laws. ${ }^{46}$ The UNHCR's mandate regarding statelessness derives from a United Nations General Assembly Resolutions on this matter:

Considering the Convention on the Reduction of statelessness of 28 August 1961 and, in particular, Articles 11 and 20 requiring the establishment of a body to which a person claiming the benefit of the convention may apply for the examination of his claim and for assistance in presenting it to the appropriate authority. Requests of the Office of the United Nations High Commissioner for Refugees provisionally to undertake the functions foreseen under the convention on the Reduction of Statelessness in accordance with its Articles 11 after the convention has come into force ${ }^{72}$

The UNHCR has further been mandated to continue to perform these functions on a priority basis under the resolution. ${ }^{73}$ So far activities pursued under this mandate have been limited, but given the magnitude and the complexity of the problem, especially in the former USSR, it appears essential for the UNHCR to strengthen its efforts to provide a pragmatic umbrella of solutions. However, this would require primarily a clearer definition of its mandate.

70 Report of the Ad Hoc Committee on Statelessness and Related Problems, UN Doc. E/1618 and Corr. 1,17 Feb. 1950, 120.

71 Article 1 (A), UN Convention Relating to the Status of Refugees, 1951 with its Additional Protocol, 1967

72 Limpert, supra nt 3, 30.

73 UN General Assembly, Question of the establishment, in accordance with the Convention on the Reduction of Statelessness, of a body to which persons claiming the benefit of the Convention may apply, 10 December 1974, (2311th plenary meeting), A/RES/3274(XXIX). 
The United Nations General Assembly should define the content of the mandate entrusted to the UNHCR by adopting a separate and distinct resolution thereon. This would ensure that the UNHCR would act as the body established under Article 11 of the 1961 Convention. Consequently, the UNHCR should have a supervisory role in the implementation of that Convention including a responsibility to develop a reporting system that informs the UN General Assembly on a regular basis with respect to matters concerning statelessness.

The UNHCR would also have a similar supervisory function concerning the implementation of the 1954 Convention on the Status of Stateless Persons, as both conventions are clearly interlinked. With a more active, clear, and precise mandate the UNHCR would then be in a position to be more active in both the promotion of these two international instruments as well as finding durable and permanent solutions to prevent and to reduce the menace of statelessness. These new capabilities would form part of the comprehensive approach and humanitarian understanding that has been advocated on numerous instances by the UN High Commissioner.

This will also require that the Executive Committee of the High Commissioner's program adopts a decisive and logical conclusion to strengthen the office's mandate concerning statelessness as part of the overall strategy to prevent and mitigate movements of unprotected and persecuted persons. Ultimately, this will also establish a closer link with other organs of the United Nations system dealing with nationality issues and establish a link between the United Nations Centre for Human Rights and the International Law Commission.

\section{Statelessness: A Global View}

The Tatar family members are among the countless people around the world who do not have a country they can call home. They are persons who are not recognized by any state as citizens. Trapped in this legal limbo they enjoy only minimal access to national or international legal protection or to basic rights such as health, education and political choice in electing their representatives. Effectively, they are outcasts ${ }^{74}$ from the global political system of the nation-state, which has evolved in the last century. ${ }^{75}$ The UDHR unequivocally states that "everyone has the right to a nationality" ${ }^{76}$ and that "no-one shall be arbitrarily deprived of his nationality. ${ }^{77}$ But millions of people across the world still need the security and protection under the citizenship laws. A considerable number of the world's stateless persons are also victims of forced displacement. In some cases, persons and communities are deprived of their nationality by governmental diktat and are consequently banished from the country, which they believe to be their home. ${ }^{78}$ In other circumstances, stateless people are compelled to flee because of the persecution and discrimination where they have lived for most or all their lives. Stateless people subsequently find it impossible to return to their motherland. Thus, statelessness is not only a cause of human insecurity and a basis of forced displacement, but may also present a danger to national and regional stability.

In this context, citizenship questions have developed into a focal characteristic of the modern world, causing tension and even violence between states and societies.

\footnotetext{
74 Definition of outcast: 'One that has been excluded from a society or system.' - The Free Dictionary.

75 Thompson, WR, Evolutionary Interpretations of World Politics, (Routledge 2016); See also UNHCR, "New Delhi" 229, World Focus (1999), 22-23.

76 Article 15, Universal Declaration of Human Rights 1948.

77 Ibid.

78 UN Department of Social Affairs, A Study on Statelessness (United Nations 1949).
} 
Humanitarian organizations have an important role to play in preventing such conditions, protecting stateless people and finding just solutions to their predicament. At last, the problems of statelessness and contested nationality can only be effectively addressed through the actions of states themselves. Therefore, the family had been in exile for decades, but when the Crimean Tatars eventually returned to their ancestral homeland they dreamed of a new beginning. Instead, the Tatars found themselves virtually as non-persons. The family was not allowed to own property, find work in nearby towns or even menial farm jobs. During the harsh winter months, four generations of the family huddled together in a single room. When the family's father suffered a fatal heart attack searching for wild berries and roots to feed his wife and children there was no dignity in death; without the proper papers he could not be officially buried. ${ }^{79}$

The above mentioned problem of statelessness has been fuelled by a bewildering vortex of complex developments ranging from sweeping political changes such as the disintegration of the former Soviet Union and former Yugoslavia, disagreements about descent, ownership, tribal affiliations, the role of women and children and power balances between different ethnic groups. These issues have put the statelessness issue once again on the international agenda.

The Tater family and other Crimeans mentioned above, for instance, were among an estimated 250,000 ethnic Crimeans originally deported by Stalin in 1944 who returned 'home' following the collapse of the Soviet Union to what is modern-day Ukraine. An estimated 17,000 Tatar Crimeans returned stateless, though the majority had already acquired another nationality, such as Uzbek citizenship, or were granted Ukrainian citizenship on independence in 1991. The government faced the tricky dilemma of how to successfully integrate large numbers of people who, while enjoying strong historical links with the region, had few legal ties, and, thus, few rights such as access to work and social services. Many returning Tatars had their own headache: whether to run the risk of surrendering their existing citizenship with no guarantee that they would obtain Ukrainian nationality. ${ }^{80}$

When Czechoslovakia split into two sovereign states in 1992-93, some people were caught in a strange no-man's land. They voted in the Czech Republic where they had lived physically for years. Overnight, however, they were deemed to be citizens of the neighbouring Slovak Republic. To qualify for Czech citizenship, they had first to establish their Slovak status, renounce this citizenship rendering them temporarily stateless, and then apply for Czech nationality. If they were refused, they remained stateless, as happened to some Roma. These individuals were then dependent on Slovak authorities to agree to reinstate their Slovak identities. ${ }^{81}$

A world away in Asia, a group of several hundred ethnic Chinese who fled Vietnam to Hong Kong during the exodus of the boat people in the 1970's and 1980's remain trapped in a similar legal and politically charged labyrinth today. Hundreds of thousands of Vietnamese boat people resettled in new countries or eventually returned to Vietnam. There were more than half a million ethnic Chinese who fled directly to the People's Republic and were integrated there. These Chinese, however, became, in legal terms, 'unclaimed'. Hanoi refused to take them back because they were not citizens,

79 UN General Assembly, Question of the establishment, in accordance with the Convention on the Reduction of Statelessness, of a body to which persons claiming the benefit of the Convention may apply, 30 November 1976, (83rd plenary meeting) A/Res/31/36.

80 Ibid.

81 Ibid. 
China turned them away and they did not qualify for residency status in Hong Kong, which subsequently reverted to Chinese rule. ${ }^{82}$

Even if a country agrees to consider a stateless person for citizenship, rulings are often influenced by the state's historical, political and philosophical makeup. In some cases, families who have lived in a particular country for generations are refused citizenship because of their ethnicity, religion, race or even social and linguistic backgrounds. When governments change or are overthrown people can be retroactively stripped of citizenship and property, detained and finally expelled. As happened with the Asian population in Uganda when Iddi Amin seized power there in the 1970s. During the Cold War years, Romanians and Soviets who wanted to emigrate first had to renounce their citizenship with no guarantee they could obtain a new nationality. Many ended up 'stranded' without a country to call home. ${ }^{83}$

Inheriting a nationality can also be problematic and in cases where a father is stateless or divorced, individuals are often unable to pass their nationality on to their children even though they are born in their country of origin. Failure or refusal to register a child's birth can also result in statelessness. As the statelessness problem became more pronounced, a General Assembly resolution in 1996 mandated the UNHCR to broaden its role, helping to promote the avoidance and elimination of statelessness on a global scale. The UNHCR established a specific Post for Statelessness Affairs within the Organization's Division of International Protection and co-operated with states and international and regional organizations to help accession to existing conventions, strengthen national laws and promote new agreements. Thus, the Office of Stateless Affairs has worked with the Council of Europe on the 1997 European Convention on Nationality, the International Law Commission on the draft Declaration on Nationality following state succession, the Office of the High Representative in drafting new citizenship laws for Bosnia and Herzegovina, and the Organization for Security and Cooperation in Europe (OSCE) in developing programs for minorities. ${ }^{84}$

The UNHCR worked closely with Ukrainian authorities, launching a widespread public information campaign including television videos, posters and brochures and establishing a local non-governmental organization named Assistance To Offer Legal Advice to the Tatar Family on citizenship issues. The results have been encouraging. In 1997-98, 4,500 returnees were given Ukrainian citizenship compared with 150 between 1992-96. Additionally, the Czech Republic, with assistance from the UNHCR, has begun a process of reviewing individual cases in that country and hundreds of individual who previously were unable to acquire Czech citizenship had their cases successfully reviewed. This has become a precedent for the development of similar programs in other countries.

The Universal Declaration of Human Rights (UDHR) stipulates that everyone has the right to a nationality. Each state has nationality laws, and citizenship is one of the most precious gifts any governments can bestow. But in an era of increasing ethnic tension, mass migrations of people, and governments, which are even more reluctant to welcome refugees or other groups, the number of stateless persons appears bound to continue growing for the foreseeable future.

$\begin{array}{ll}82 & \text { Ibid. } \\ 83 & \text { Ibid. } \\ 84 & \text { Ibid. }\end{array}$ 


\section{A. Statelessness in South Asia}

South Asia is a region where most refugees indulged in violence along the route while leaving their original homelands and heading to their new respective destinations in India and Pakistan after the partition of India in 1947 resulting in the harried and terrified refugee movements owing to ethnic tensions, socio-economic problems, political cleavages and religious persecution for centuries. ${ }^{85}$ Indeed, some of the largest and most fraught movements of refugees in human history have taken place in this region of the world. $^{86}$ Since 1947 around 40 million people have crossed international borders in the South Asia region as displaced persons or refugees. ${ }^{87}$ India and Pakistan experienced a heart-wrenching spectacle of partition and resultant migration, the scars of which are still fresh and haunt those even with ephemeral memory. ${ }^{88}$

Statelessness in South-Asia is still existent, owing to the partition of the Indian sub-continent and internal armed conflict in various countries of the region. The Partition of India displaced the Biharis in $1947 .{ }^{89}$ With the breakup of Pakistan and the formation of Bangladesh in 1971, the Biharis were displaced a second time, giving rise to their international status as refugees. However, this status has seldom been recognized in international law. ${ }^{90}$ The creation of Bangladesh began a process of denationalization of Biharis by Pakistan. In this context, the international law relating to territorial change and the deprivation of nationality of Biharis raises issues of their status as de facto stateless refugees. ${ }^{91}$

The communal violence after the partition of India in 1947, preceded by the socalled Great Bihar Killing of 30,000 Muslims in October-November, ${ }^{92}$ resulted in a largescale movement of Muslims into the newly created province of East Pakistan. Consequently, a million refugees migrated into East Bengal in 1947. ${ }^{93}$ It was estimated that 95.9 per cent of these refugees came from the eastern Indian states of Bihar, West Bengal, Assam, Orissa, Nagaland, Manipur, Tripura and Sikkim. ${ }^{94}$ Although Pakistan was successful in gaining her independence as a theocratic state, it had an ethnically plural society. From the beginning, the crises of national integration and the assimilation of refugees from India created more complexities than solutions, an insider $v / s$ outsider syndrome and the existential problem of lack of acceptance and assimilation of the Bihari refugees in East Pakistan. ${ }^{95}$

The culture of Bihari refugees contributed to defining the ethnic boundary between them and the majority Bengali residents. Besides, when the West Pakistan feudal elite began to capture economic and political power in East Pakistan, the Biharis, who shared the linguistic background of the elite, began to covertly identify with them. Their ethnic identity became important in various sectors of the East Pakistani economy,

\footnotetext{
Ibid.

86 Ahmad, Nafees, Refugees in South Asia \& Human Rights, National Workshop on Human Rights of Refugees, Political Science Department-AMU \& UNHCR, Feb. 23, 1999, India.

87 Ibid, 7.

88 Ibid, 7.

89 Ibid, 7.

90 Summit Sen, Stateless in South Asia, Seminar 463 (1998), 49.

91 Ibid.

92 Ibid.

93 Hashmi, T, The Bihari Minorities in Bangladesh: Victims of Nationalisms, (1996), at <http://www.statelesspeopleinbangladesh.net/uploaded_files/articles/TheBihariMinoritiesInBanglade sh.p $>$ (accessed 10 May 2017).

94 Whitaker, B, The Biharis in Bangladesh, 4th ed, (Minority Rights Group, London, 1982) 7.

95 Chowdhury, E, Non-Bengali Refugees in Bangladesh: Patterns, Policies and Consequences in Rogge, J, ed, Refugees: A Third World Dilemma (Rowman and Littlefield, New Jersey, 1987) 220.
} 
and the Bengali majority found the Biharis in a relatively privileged position in getting official patronage. In fact, Biharis acquired the nationality of Pakistan as a precondition to resettlement and priority was given to the Muhajirs (refugees in Urdu language) by public policy measures, especially 'in railways, post and telegraph, armed forces, private industries, trade and commerce'. ${ }^{96}$

The process of the disintegration of Pakistan in 1971 led to two simultaneous major refugee movements. The first was the escape of an estimated 10 million refugees into India in the aftermath of the brutal massacre of the Bengali populace and the second flight consisted of the minority Biharis fleeing into refugee camps as a result of the extermination during the liberation struggle. Moreover, thousands of Biharis were brutally massacred, with the Bengali petty bourgeoisie and working class engaging in ethnic cleansing and, unfortunately, the same spectacle of massacre was recently witnessed in Kosovo. The pogrom of Biharis was vividly described by Anthony Mascarenhas:

Thousands of families of unfortunate Muslims, many of them refugees from Bihar ... were mercilessly wiped out. Women were raped and had their breasts torn out with specially fashioned knives. Children did not escape the horror: the lucky ones were killed with their parents' but many thousands of others must go through what life remains for them with their eyes gauged out and limbs roughly amputated. More than 20,000 bodies of the non-Bengalis have been found in the main towns as Chittagong, Khulna and Jessore. ${ }^{97}$

Since Urdu was the lingua franca, the Biharis had tended to associate themselves with West Pakistan. Then the West Pakistanis landlords and Urdu-speaking capitalists captured economic and political power in East Pakistan; the Biharis shared their political gain. The government policy of favoritism and isolation of the Bihari community from the Bengali majority led the Biharis to tie their fate to that of the West Pakistani political elite. A majority of Biharis had voted for the Muslim League and Jamat-I-Islami in the elections. Besides, when the Awami League began to grow as an influential political party of the bourgeoisie and middle class, then they found their West Pakistan counterparts to be a hindrance to their prosperity. Consequently, Awami League with their limited approach failed to include Bihari class-consciousness. The Bengali political elite in East Pakistan focused on Urdu as an issue to denounce the repressive attitude of West Pakistan. While it inspired the majority in East Pakistan, it aggravated the alienation of the Biharis, which made them lean towards the West Pakistanis. The Bengalis were initially sympathetic towards the oppressed Biharis, however, Bengalis gradually became suspicious of their exclusive attitude and political activities. ${ }^{98}$

It is understood that political opinion, within substantive limitations in human rights, can be defined as any opinion on any matter in which the machinery of state, government or policy may be engaged or involved. The political opinion of the Bihari community led it to be pursued by a majority-led government and its entities, particularly where the former addressed the unity of the eastern and western wings of Pakistan. The political agenda of the Bihari community exposed it to the reality of persecution.

96 Begum, K, "The Stranded Pakistanis in Bangladesh and International Implications" International Centre for Ethnic Studies (1989) 9.

97 See Southwick, K, "The Urdu-speakers of Bangladesh: An Unfinished Story of Enforcing Citizenship Rights" in Blitz, BK and Lynch, M, eds, Statelessness and Citizenship: A Comparative Study on the Benefits of Nationality (Edward Elgar, 2011), 119.

98 Mascarenlia, A, "The Rope of Bangladesh" (1971). 
Although political opinions may or may not be expressed, they might become the attributive features for the determination of refugee status. Since the Biharis had expressed their political will, and as a result suffered repressive measures, their fear can be clearly evidenced as well founded.

The first political step in formulating categories of non-Bengalis to be accepted in Pakistan began with the recognition of Bangladesh as an independent state. This was primarily because President Bhutto of Pakistan needed to negotiate the return of 93,000 POWs held captive in Bangladesh. However, he was equally anxious to see that the one million Biharis did not move to Pakistan. Pakistan agreed by the New Delhi Agreement of 28 August 1973 to transfer a substantial number of "non-Bengalis" in Bangladesh who had opted for repatriations to Pakistan, in exchange for Bengalis in Pakistan and the return of POWs. He engaged the ICRC as the route for all applications for repatriation from Biharis to the Government of Pakistan. However, the ICRC made it clear that 'registration with the ICRC does not give a right to repatriation. The final acceptance ... lies with [the] Pakistan and Bangladesh governments.' Pakistan began issuing clearances in favor of those 'non-Bengalis' who were either (i) domiciled in former West Pakistan, (ii) were employees of the central government and their families, or (iii) were members of divided families, irrespective of their original domicile. ${ }^{99}$ Second, it can be argued that the category of divided family applied by Pakistan was unilaterally determined and was more restrictive than that identified by the ICRC in their letter requesting options regarding repatriation. It is estimated that 76 percent of Bihari families remain divided because of the restrictive definition of divided families, since grandparents, parents, and unmarried siblings were not considered part of the same family for the issuance of documents clearance. Bangladesh has asserted the need for the acceptance of a broader and Islamic definition of the family that includes the aforementioned family members based on the western concept of the family, as the present definition is narrow and restrictive. This argument upholds family reunification as one of the fundamental provisions of refugee law in any effective resolution procedure ${ }^{100}$ but it was applied unilaterally by Pakistan. Third, it had been agreed between Pakistan and Bangladesh that the antecedents of the persons who returned to Pakistan as a hardship case would be examined. Were it to be established that they fell within the other two categories, then the additional category of hardship cases would be included. At the outset, the definitional and numeric limits of the hardship cases have caused a legal anomaly since it needs to be explained why Pakistan limited the number of repatriations to 25,000 . In reality, the hardship cases had essentially included Biharis who fell within the other two categories and certainly were not war victims, orphans or disabled persons. Over the years, Pakistan has failed to give a breakdown of the number of persons listed under the categories and the vacancies in the hardship category. On the other hand, the repatriation figures over the last 45 years have seen a decrease. To date, an estimated 178,069 Bihari refugees have returned to their country of former habitual residence.

While practice has left a majority waiting to return home, Pakistan certainly needs to do much more to assure the Bihari refugees and the international community that there is a solution of this protracted crisis. ${ }^{101}$ Therefore, the resort to denationalization of Biharis by Pakistan is an abuse of human rights and fundamental freedoms under international law, constituting an attempt to throw off the duty of admission and thereby casting an illegal burden on the state of residence.

\footnotetext{
99 Ibid, 52.

100 Ibid, 54.

101 Ibid, 54.
} 


\section{B. Statelessness in India and National Legal Protection}

India has also proved to have human sufferance and agony. It has around 65,000 Chakma and Hajong refugees who are primarily stateless in the north-eastern state of Arunachal Pradesh along with some sporadic groups of Bihari Muslims in various pockets of northeast India. The stateless persons in India do not have a bright future owing to the absence of a legal structure at national level. India has not acceded to the UN Convention on the Reduction of Statelessness of 1961, nor has the 1951 Convention with its Additional Protocol of 1967 been signed. In such a situation, stateless persons have an uncertain and bleak future in India.

It is, thus, incumbent on the Government of India to abandon its silence with respect to laws for refugees. The country can no longer depend and continue to deal with problems and issues of refugees by resorting to the archaic $19^{\text {th }}$ century principles enshrined in the outdated Foreigners Act of 1946 and the Extradition Act of 1962. India has always been, and remains magnanimous in providing shelter and asylum to people who are fleeing conflict. Nevertheless, as the country became a member of the UNHCR Executive Committee in 1995 and has since been playing a pivotal role in pushing for reformulating and redefining international legal instruments, such as the 1951 Convention on refugees, by incorporating present day realities of refugees' situations, it must also draft a domestic law on refugees to endorse its actions ${ }^{102}$ at the international level.

\section{Divine Laws on Nationality and Statelessness}

Individual dignity has been accorded a high status in the scheme of Islamic law and the concept of human rights fits naturally within this structure. ${ }^{103}$ The Islamic tradition also ordains sympathetic treatment to the rehabilitation of refugees who are forced to abandon their homes and hearts on account of persecution. Indeed, living in one's homeland, including one's kith and kin is a recommended course of action for Muslims to escape persecution for protecting their religious beliefs or social traditions. ${ }^{104}$ Thus, Islamic Law stipulates an order to provide protection and assistance to persons in need. The Quran is replete with references to the earliest Muslim community and the Jews and Christians that came before them as the persecuted people. ${ }^{105}$ According to the Holy Quran

Those who have believed and have chosen exile, and have fought for the faith, and those who have granted them help and asylum: these are the true believers. (Q4:97 \& Q7:127)

The Prophet (PBUH) recommended this course in the early days of his mission to the few believers facing cruelties and harassment from society, asking them to migrate to Habsha (Abyssinia) to save them from religious persecution. Later, the Prophet (PBUH) himself, along with his companions, migrated from Mecca to Medina, when their oppression by the Meccans became intolerable. The people of Medina received them with open arms and open hearts, offered them not just shelter but also materials, such as

\footnotetext{
102 Ibid, 54.

103 Ahmad, N, "People without Homes" The Pioneer (1999) 9.

104 Weeramantry, CJ, "Islam and Human Rights" in Weeramantry, CJ, ed, Islamic Jurisprudence: An International Perspective (Palgrave Macmillan, UK, 1988) pp. 113.

105 The Holy Quran: Q7:137.
} 
land for cultivation, and made them partners in their businesses. Indeed, this migration laid the foundations of the first Islamic state. Islamic traditions not only recognize the right of asylum but, in dire need, encourage people to avail themselves of it. It is, as already observed, a recommended course of action for Muslims to follow, not only to escape religious persecution, but also for seeking economic development and prosperity. ${ }^{106}$

The warning against persecution occurs 299 times in the Holy Quran. ${ }^{107}$ The Quranic verse 'La, Allah enjoineth justice and kindness' (XVI: 90) makes just standards of behavior mandatory for all and towards all. The Arabian Muslims in their early stages had suffered gravely from the worst type of religious persecution. So, they recognized the principle of granting asylum to those who had been persecuted for their religious belief. ${ }^{108}$ The Holy Quran further strengthens this view by declaring:

If one amongst the pagans

Asks thee for asylum

Grant it to him

So that he may hear the Word

Of Allah and then escort him

To where he can be secure. (al-Quran, 9: 6)

Islam asks its followers to fight against religious persecution and help the persecuted by granting them safe passage and even asylum if they demand it. ${ }^{109}$ Islam also preaches universal brotherhood and fraternity irrespective of geo-political demarcations. In an Islamic state every person has the right to acquire property and freedoms indispensable for a dignified survival such as, inter-alia, the right to nationality.

The famous Khilafat Movement in the early 1920s of the Muslims of the subcontinent should be seen from the same perspective. There was no threat to the Muslims regarding their existence nor was there any fear of persecution, yet, they migrated to Afghanistan, simply as a protest against the invasion of Turkey by the Allied Forces in the aftermath of the First World War and the danger this posed to the Islamic Institution of the Caliphate. ${ }^{110}$

Moreover, the Universal Islamic Declaration of Human Rights adopted by the Islamic Council of Europe on 19 September 1981 declares under Article IX as to the 'Right to Asylum' in the following words

a) Every persecuted or oppressed person has the right to seek refuge and asylum. This right is guaranteed to every human being irrespective or race, religion, colour and sex.

b) Al-Masjid Al Haram (the sacred house of Allah) in Mecca is a sanctuary for all Muslims.

Thus, Islam, as a divine law or revealed law, provides a complete mechanism for the regulation of human behavior in its numerous manifestations. Islam seeks a process of universalization of human happiness and brotherhood.

\footnotetext{
106 Hasan Shah, N, "Pakistan: Policies and Laws with Reference to Refugees" (1997) Seminar on Refugees in the SAARC Region: Building a Legal Framework, 34.

107 Ibid.

${ }_{108}$ Moussa, Islam and Humanity's Need of It, (Cairo, 1966).

109 Ali, A, "Al Quran and Human Rights" Hamdard Islamicus, XII (1989) No.3/Autumn, 35-36.

110 Ibid.
} 


\section{Conclusion}

It is evident from the above discussions and deliberations that when a person does not possess the nationality of any State, he is referred to as a stateless person. Individuals may be without nationality knowingly or unknowingly, intentionally or through no fault of their own. For instance, when illegitimate children are born in a State which does not apply jus soli to alien mothers under whose national law the children do not acquire the father's nationality, or where a legitimate child is born in such a State to parents who themselves have no nationality the child becomes a stateless person. Statelessness may occur after birth as well. For instance, it may occur as a result of deprivation or loss of nationality by way of penalty or otherwise.

All individuals who have lost their original nationality without having acquired another are, in fact, stateless persons. A stateless person does not enjoy all rights that are conferred on a person in International Law. For instance, their interest is not protected by any State; they are refused the enjoyment of rights, which are dependent on reciprocity.

The Universal Declaration of Human Rights, after considering the gravity of the problem, provided under Article 15 that each person is entitled to have a nationality and the nationality of any person cannot be taken arbitrarily. A Conference of Plenipotentiaries convened by the Economic and Social Council to regulate and improve the status of stateless persons adopted the Convention relating to the Status of Stateless Persons on September 28, 1954. The Convention came into force on June 6, 1960. Presently, the convention has 44 States Parties. The Convention defined the term stateless person as a person who is not considered a national by any State under the operation of its law. The Convention gave such persons judicial status but no provision was made to reduce or eliminate statelessness. The General Assembly expressed its desire on December 4, 1954, that an International Conference of Plenipotentiaries be convened to adopt a convention for the reduction or elimination of future statelessness as soon as at least twenty States had communicated to the Secretary-General their willingness to cooperate in such a Conference. The Conference, which met at Geneva on March 24 to April 18, 1959, adopted provisions aimed at reducing statelessness at birth but failed to reach agreement on how to limit the freedom of States to deprive citizens of their nationality. Consequently, the conference met again in New York from August 15 to 28, 1961, and adopted a Convention on the Reduction of Statelessness. The Convention was opened for signature on August 30, 1961, and it came into force on December 13, 1975.

The convention under Article 1 stated that a Contracting State shall grant its nationality to a person born in its territory who would otherwise be stateless

a) at birth, by operation of law, or

b) upon an application being lodged with the appropriate authority, by or on behalf of the person concerned.

Para 3 of Article 1 further stated that a child born in wedlock in the territory of a Contracting State, whose mother has the nationality of the State, should acquire at birth that nationality if it otherwise would be stateless.

The Convention followed the idea adopted by the Convention on the Conflict of Nationality Laws of 1930 by making a provision that if the law of a Contracting State requires deprivation of nationality as a result of any difference in the personal status such as marriage, dissolution of marriage, legitimation, acknowledgment or adoption, such 
deprivation shall be provisional upon possession or acquisition of another nationality. Therefore, Article 6 of the Convention stated that if the law of a Contracting State provides for loss of its nationality by a person, spouse or children as a consequence of that person losing or being deprived of that nationality, such loss shall be conditional upon their possession or acquisition of another nationality.

The above efforts to eliminate or reduce statelessness have only had limited effects in so far that the determination of nationality is still within the competence of each State. In this respect it appears unsurprising that nationality and statelessness issues have acquired crisis proportions under the scheme of contemporary international law. Respective governments including the Government of India must strive to evolve a legal structure regarding reduction of statelessness and formulating nationality laws build on humanitarian premises. Moreover, the right to the country of origin or habitual residence must be respected by the national governments. The competence of the UNHCR with regard to the matters of nationality and statelessness must be expanded, re-formulated and re-defined while taking into account state concerns and individual claims in a new World Human Order. 